Sri Lankan J. Biol. 2018, 3 (1): 44-51

DOI: http://doi.org/10.4038/sljb.v3i1.17

Research Article

Open Access

\title{
A PRELIMINARY STUDY ON EFFECT OF BUDDHIST PIRITH CHANTING AND POP MUSIC ON THE GROWTH AND YIELD PERFORMANCE IN RICE (Oryza sativa L.)
}

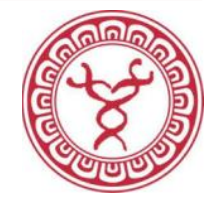

Munasinghe D.S.P. ${ }^{1}$, Liyanage K.C.M. ${ }^{1}$, Weerakoon S.R. ${ }^{1 *}$, Somaratne S. ${ }^{1}$, Dissanayake D.M.L.C. ${ }^{1}$

${ }^{1}$ Department of Botany, The Open University of Sri Lanka, Nawala.

\section{Abstract}

Music influences the growth of plants through either promoting or restricting the growth of plants. The effects of Pirith chanting and pop music were focused in the present study. Seeds of Two (02) rice varieties (Bg300 and Kaluheenati) were subjected to dormancy break treatment, kept in a soundproof confined chamber and arranged in Completely Randomized Design (CRD) with two (02) replicates and 10 seeds per replicate. Seeds were allowed to germinate under the sound rhythms; pop music, Pirith chanting and silence separately in sound proof chamber. A set of pop songs and Thunsuthra in Pirith chanting were chosen as the two (02) sound rhythms. Seeds were kept under silence served as the control. Music and Pirith were played separately for an hour, at $30 \mathrm{~cm}$ distance away from the seeds with an intensity of 55-60 dB for seven (07) days continuously, maintaining equal environmental conditions. Following seven (07) days, the percent germination was recorded. The same germinated seeds were planted in plastic pots filled with paddy soil, up to $3 / 4$ of the total depth and pots were arranged in Completely Randomized Design (CRD) with two (02) replicates and five (05) plants per replicate. Following one week, plants were subjected to the sound rhythm treatments and silence separately for three (03) months continuously. Measurement on growth and yield performance were recorded every fortnight. Significantly different $(\mathrm{p}<0.05)$ in growth and yield performances were observed under Pirith and pop music. Considerably higher rates of growth and yield were observed for varieties exposed to Pirith and comparatively, the effect of Pirith on growth and yield performance was higher with respect to pop music thus implying that the rhythmic chanting of Pirith is the most appropriate type music that improved the growth performance of Oryza sativa.

Key words: Buddhist chanting, Oryza sativa, Pirith, Pop music

*Corresponding author: Tel: 0112881383. E-mail: shyamaweerakoon@gmail.com

https://orcid.org/0000-0003-0975-2738

This is an open-access article distributed under the terms of the Creative Commons Attribution License, which permits unrestricted use, distribution and reproduction in any medium, provided the original author and source are credited. 


\section{Introduction}

Plants are complex multi-cellular organisms considered as sensitive as humans for initial assaying of effects and testing new therapies (Dossey, 2001). Sound has always been considered a fundamental part of life on earth and is known to effect the growth of plants and plants respond to music the same as humans do. Although many known species in animals are known to communicate with each other through sounds and wave patterns, the involvement of plants with sound production or recognition has hardly been talked about. However, mounting scientific evidence does appear to suggest that plants could be capable of recognizing and responding to sound in nature and to sounds produced by human beings (Collins and Foreman, 2001).

The studies on the effect of music on plants date back to1955 and the pioneers of sound experiments on plants, Singh and Ponniah (1955) played incomprehensible violin pieces intermittently to plants at certain times of the day and observed some responses of plants to sounds (Collins and Foreman, 2001). However, the results obtained from these experiments were vague since limited details are available on the abovementioned study. In 2014, Vanol and Vaidya carried out an experiment to investigate the effect of sound (music and noise) on cluster beans (Cyamopsis tetragonoloba) with varying frequencies.They reported that the germination and growth were profoundly higher compared to the control when seeds of above plants were exposed to classical music and rhythmic rock music with higher frequencies. Over the time, studies on effect of sound on plant have been carried out, focusing different types of music including classical, jazz, pop, rock, acid rock, East Indian, and Country (Retallack, 1973). Results of these experiments have demonstrated that music such as rock and acid rock have negative effect on plants while classical, jazz and Indian classics are supportive for plant growth (O'Donnell, 1999).

The effect of religious chanting on plant growth had been studied in many centuries around the world including India, China and Nepal. Although, reports of research on effect of Pirith on plant growth are limited, in India, mantras in Hindu veda, such as Gayathri mantra and Agnihotra have been used to test their effect on plant growth performances. These studies have shown that Gayathri Mantra has a remarkable influence on the growth of medicinal plants and an efficacy of curing diseases in certain plants (Karnick, 1983). These Mantras have also shown an overwhelming effect on seed germination and growth on rice plants (Devi et al. 2004). Farmers in Fujian Province in East China, have stated that Buddhist chant playing in the paddy fields has helped to increase rice production by $15 \%$ and also yielded larger grains, while the paddies with no music suffered from pests (BBC, 2014).

In Sri Lanka, the cultivation of rice goes back to many centuries. In the ancient times, farmers had a long belief that use of Pirith chanting and sprinkling of Pirithchanted water to paddy fields during bearing time (i.e. initiation of panicles) would bring higher yields. Therefore, the objective of the present study was to investigate the effect of two (02) sound rhythm treatments, Pirith chanting and pop music.on growth and yield 
performance of two (02) rice varieties of Sri Lanka.

\section{Material and Methods}

Two rice varieties (Bg300 and Kaluheenati) were obtained from Rice Research and Development Institute, Batalagoda, Sri Lanka. The experiments were carried out in soundproof confined chambers in the Research Laboratory of the Department of Botany at the Open University of Sri Lanka, Nawala, Sri Lanka.

Seeds were subjected to dormancy break at $50{ }^{\circ} \mathrm{C}$ for five days and subsequently surface sterilized by keeping them in 70\% alcohol for two minutes. Seeds were washed thoroughly with distilled water and dipped them in $2 \%$ Clorox for about 30 minutes. Finally, the seeds were thoroughly washed with distilled water, kept in the soundproof chambers and arranged in a Completely Randomized Design (CRD) with two (02) replicates and 10 seeds per replicate. Seeds were allowed to germinate under two sound rhythms; pop music and Pirith, separately. A set of pop songs and Thunsüthra (Karaneyameththasüthra, Rathanasüthra, Mahamangalasüthra) were selected for the experiment. The seeds exposed to silence were treated as control. Music and Pirith were played separately for an hour, at $30 \mathrm{~cm}$ distance away from the seeds with an intensity of $55-60 \mathrm{~dB}$ for seven (07) days continuously, maintaining equal environmental conditions (Vanol and Vaidya, 2014). Following seven (07) days, based on the observation, the percent germination (Germinated seeds/Total seed $x$ 100) was calculated (Krishnasamy and Seshu, 1989).
The germinated seeds of the previous experiment were planted in plastic pots filled with paddy soil, up to $3 / 4$ of the total depth and pots were arranged in Completely Randomized Design (CRD) with two (02) replicates and five (05) plants per replicate. One week after planting, the experiment was commenced. The same sound treatment procedure as described earlier was applied to all the plants for three (03) months continuously, while maintaining other environmental conditions constant. Growth performance indicators; plant height, chlorophyll content, number of leaves, leaf length, tillers and dry weight of plants (three plants per replicate were destructively sampled) and yield performance indicators; days for bearing, number of panicles, spicklets, numbr of seeds, 1000-grain weight and field grain percentage (seeds/spicklets) x 100) were recorded . All statistical analyses (descriptive statistics, multiple range comparison - LSD and nonparametric range tests ( $\mathrm{Z}$ test) were carried out using SPSS PC (Ver.23) (2015).

\section{Results}

Two way ANOVA results with the interaction terms (Var*Trt) is shown in Table 01. According to table, the interactions between sound treatment and rice variety were marginally significant at $p=0.042$. Therefore, the adjusted calculated means were given in the table indicated that there was a significant difference between the treatments. The variations between the treatments indicate the significant difference in sound rhythms treatments and a significant difference between the pop music and Pirith on the seed germination $(p=0.001)$. There was no significant difference between the rice 
varieties to the different sound rhythm treatments $(p=0.150)$. Therefore, both varieties, Kaluheenati and Bg300 indicated a $10 \%$ increase in percent germination under Pirith and music (92\% and $81 \%$ respectively). The response of the same varieties to pop music indicated an average germination percentage between Pirith and silence conditions.

The variation of plant height, leaf length, chlorophyll content and dry weight were shown in Table 02. Compared to pop music and silence, 1000 seed weight of Kaluheenati and Bg300 have indicated a statistically significant increased in response to Pirith ( $\mathrm{p}<0.05)$. However, the mean plant height difference was statistically significant $(\mathrm{p}<0.05)$ under the treatment of Pirith. An increased mean leaf length and mean chlorophyll content were observed in both varieties under Pirith. Although, an apparent difference in the magnitude of leaf length and chlorophyll content in both varieties for Pirith was observed, there was no significant difference between pop music and silence (Table 02). Meanwhile, an enhancement in the dry weight of the plants was noticed under Pirith whereas plants under pop music showed a decrease in dry weight.

Further, the results revealed that the differences between the growth parameters of plant height, leaf length, chlorophyll content and dry weight of plants grown under Pirith and pop music $(\mathrm{p}<0.05)$ (Table 2). Nevertheless, the variation of leaf chlorophyll content, leaf length and dry weight of plants under the pop music treatment were comparatively insignificant with respect to the control $(\mathrm{p}$ $>0.05)$. These results imply that Pirith chanting influence the growth performance of the rice plants.

Table 1: Rice grain germination under three treatments (Pirith, pop music and silence). Different letters in columns indicates a significant difference relevant to the treatment given.

\begin{tabular}{|c|c|c|c|c|}
\hline \multirow[b]{2}{*}{ Treatment } & \multirow{2}{*}{$\begin{array}{c}\text { Mean } \\
\text { (Percent } \\
\text { germination) }\end{array}$} & \multirow{2}{*}{$\begin{array}{c}\text { Std. } \\
\text { Error }\end{array}$} & \multicolumn{2}{|c|}{$95 \%$ Confidence Interval } \\
\hline & & & Lower Bound & Upper Bound \\
\hline Control & $77.667^{\mathrm{a}}$ & 1.063 & 75.351 & 79.982 \\
\hline Music & $81.333^{b}$ & 1.063 & 79.018 & 83.649 \\
\hline Pirith & $91.500^{c}$ & 1.063 & 89.184 & 93.816 \\
\hline
\end{tabular}

Dependent: Percent Germination

\begin{tabular}{lccccc}
\hline Source & Sum of Squares & df & Mean Square & F & $p$-values \\
\hline Rice Variety (Var) & 16.056 & 1 & 16.056 & 2.369 & .150 \\
\hline Treatment (Trt) & 616.333 & 2 & 308.167 & 45.467 & .000 \\
\hline Var * Trt & 56.778 & 2 & 28.389 & 4.189 & .042 \\
\hline
\end{tabular}


Table 02: Summary statistics of the parameters measures across different treatments. Since there was a significant interaction between, the variable 1000 seed weight was presented in the table for two rice varieties. Similar letters in column indicated that there is no statistically significant difference at $\mathrm{p}<0.05$

\begin{tabular}{|c|c|c|c|c|c|c|c|}
\hline \multirow[b]{2}{*}{$\begin{array}{l}\text { Sound } \\
\text { treatment }\end{array}$} & \multirow{2}{*}{$\begin{array}{l}\text { Plant } \\
\text { Height } \\
(\mathrm{cm})\end{array}$} & \multirow{2}{*}{$\begin{array}{l}\text { Leaf } \\
\text { length } \\
(\mathrm{cm})\end{array}$} & \multirow[b]{2}{*}{$\begin{array}{c}\text { Chlorophyll } \\
\text { content/plant }\end{array}$} & \multicolumn{2}{|c|}{1000 seed weight $(\mathrm{g})$} & \multicolumn{2}{|r|}{ Plant dry } \\
\hline & & & & Bg300 & Ko & $\begin{array}{c}\text { Field grain } \\
\%\end{array}$ & $\begin{array}{l}\text { Weight } \\
\text { (g) }\end{array}$ \\
\hline Control & $94.7(3.3)$ & $8.6(1.5)^{b}$ & $24,4(32)^{b}$ & $17.3(1.0)^{b}$ & $8)^{b}$ & $33.3(7.7)^{b}$ & $3.8(0.9)^{b}$ \\
\hline & $T(1)$ & $0.2(1.2$ & & $17.3(0.6)^{b}$ & $0.1(0.6)^{b}$ & 30.7 & $3.6(0.4)^{b}$ \\
\hline Pirith & $7.6(1.1)^{\mathrm{a}}$ & $2.2(2.1)^{\mathrm{a}}$ & $8.6(0.7)^{\mathrm{a}}$ & $18.5(0.6)^{a}$ & $28.2(0.6)^{\mathrm{a}}$ & $43.5(5.0)^{\mathrm{a}}$ & $4.9(0.6)^{\mathrm{a}}$ \\
\hline
\end{tabular}

Table 3: Result of the Z-test carried out on the non-parametric growth and yield performance indicator

\begin{tabular}{|c|c|c|c|}
\hline Parameter & $(1,3)$ & $(2,3)$ & $(1,2)$ \\
\hline Number of Leaves & $-2.057^{*}$ & $-2.682^{*}$ & $-1.928^{8}$ \\
\hline Number of Tillers & $-2.666^{*}$ & $-3.58^{*}$ & $-2.536^{*}$ \\
\hline Number of panicles & $-2.536^{*}$ & $-3.446^{*}$ & $-2.536^{*}$ \\
\hline Number of spicklets. & -0.71 & -0.689 & -0.101 \\
\hline Number of seeds & -0.101 & -1.608 & -1.319 \\
\hline Days to bearing & -0.71 & $-2.527^{*}$ & $-3.145^{*}$ \\
\hline
\end{tabular}

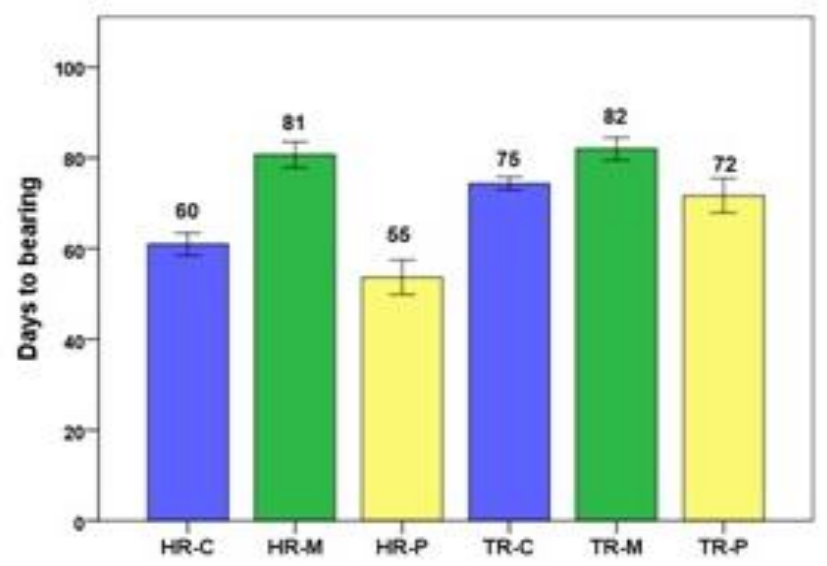

Figure 1: Effect of different sound treatments on the number of days to bearing of panicles 
Influence of sound treatments on number of days to bearing panicles was shown in Figure 01, which shows days taken to flower was comparatively lower in plants under Pirith and higher in plants under pop music. Pirith chanting has led to lower the bearing days in Bg300 and Kaluheenati (55 and 72 days, respectively), meanwhile, pop music had increased the bearing days of Bg300 and Kaluheenati (65 and 82, respectively). These results were statistically significant at $p=0.05$.

Z-test was performed to non-parametric data such as number of days for bearing, number of leaves, number of tillers, panicles, spicklets and the number of seeds and these results are shown in Table 03. The results did not show any significant difference in Pirith compared to control, but the difference with Pirith and pop music was significant $(\mathrm{p}<0.05)$ (Table 03)

Careful observation of Z-test results indicated that there was significant difference between the pair of treatments $(p<0.05)$. The pair-wise comparison of treatment indicated that significant difference in number of leaves, tillers, panicles and days to bearing indicating the effect of the treatment. The comparison of Pirith with control $(1,3)$ and pop music with control $(2,3)$ for number of leaves, tillers and panicles were statistically significant. Therefore, the results implied that sound either in Pirith or pop music promotes the growth of rice plants. The descriptive statistical results of the yield parameters of plants under Pirith and pop music treatments with regard to silence showed a significant increase in the 1000-seed weight and field grain percentage (Table 01) under the treatment Pirith for both rice varieties $(p<0.05)$ and an observable decline was observed in pop music compared to plants under silence. Further, the effect of sound treatments on rice plants was insignificant $(p>0.05)$ for number of spicklets and seeds.

\section{Discussion}

A study conducted on the effect of music with low frequencies on the germination rate has revealed that music with low frequencies increased germination rate (Creath and Schwartz, 2004). Further, the soft rhythm of music and sounds have influenced plants to grow healthier (Chowdhury and Gupta, 1999). In the present experiment, rice plants experienced soft rhythmic sounds through Pirith chanting. This could have been the reason to show significant differences in most of the parameters tested in rice plants exposed to Pirith when compared control plants. These results supported the hypothesis put forward by Chowdhury and Gupta (1999). According to Wang et al. (2003) germination index, height of stem, relative increase rate of fresh weight, activity of root system and the penetrability of cell membrane (Is it permeabllity of cell membrane?) significantly increased when rice plants were subjected to different music fragments. These findings support the results obtained from the present study. Chowdhury and Gupta (1999) further described that the increment of growth rate of plants could be attributed to increased production of proteins when appropriate tune is played. Thus, the metabolism of the plants increased when they were exposed to music. Collins and Foreman (2001) too obtained the similar results for the increment of plant height 
and yield of beans and impatiens. In the present study also, the hospitable environment for the increment of growth and yield performance of plants would have been facilitated through Pirith chanting rather than pop music.

According to O'Donnell (1999) harsh music had negative effect on plant growth and yield performance. In the present study, growth and yield parameters were declined in pop music compared to Pirith and control conditions. The declined in dry weight, 1000-seeds weight and field grain percentage indicated that pop music had a negative effect on the plant growth Thus, plants under pop music experienced a harsh environment condition for its growth and yield performance. In addition, decreasing the number of days to bearing under pirith treatment indicated that pirith facilitates early grain filling and ripening of seeds. Thus Pirith chanting could be the appropriate sound to increase the yield of rice plants.

\section{Conclusion}

Pirith chanting positively influenced growth and yield performance in two rice varieties (Bg300 and Kaluheenati) used in the study. However, further studies are needed for confirmation of these results and to elucidate the mechanism of the responses to Pirith chanting in rice using phytochemical and biochemical analyses

\section{References}

BBC, (2014) China: Soothing Buddhist music said to boost rice crop. http://www.bbc.com/news/blogs-news- from-elsewhere-29145652, Retrieved on December $19^{\text {th }} 2017$.

Chowdhury, A.R. and Gupta, A. (2015) Effect of Music on Plants - An Overview, International Journal of Integrative Sciences 4: 30 - 34.

Collins, M.E. and Foreman J.E.K (2001) The effect of sound on the growth of plants, Canadian Acoustics 29: 3-8.

Creath, K. and Schwartz, G.E. (2004) Measuring Effects of Music, Noise, and Healing Energy Using a Seed Germination Bioassay, The Journal of Alternative and Complementary Medicine 10: 113-122.

Devi, J., Swamy, N.V.C., Nagendra, H.R. (2004) Effect of Agnihotra on the germination of rice seeds Indian Journal of Traditional Knowledge 3 (3): 231 239.

Dossey, L. (2001) Being green: On the relationships between people and plants Alternative Therapies 7: (12-16): $132-$ 140.

Karnick, C.R. (1983) Effect of Mantras on human beings and plants Ancient Science Life. 2: 141-147.

Krishnasamy, V. and Seshu, D.V. (1989) Seed Germination Rate and Associated characters in Rice Crop Science 904-908.

O'Donnell, L. (1999) Music and the Brain. http://www.cerebromente.org.br/n15/m ente/musica.html, Retrieved on December $20^{\text {th }} 2017$.

Retallack, D. and Broman, F (1973) Response of growing plants to the manipulation of their environment The Sound of Music and Plants 9: 82-94. 
Wang, X. J., Wang, B. C., Jia, Y., Huo, D., Duan, C. R. (2003) Effect of sound stimulation on cell cycle of chrysanthemum (Gerbera jamesonii) Colloids and Surfaces (B: Biointerfaces) 29: 103-107.

Vanol, D. and Vaidya, R. (2014) Effect of types of sound (music and noise) and varying frequency on growth of guar or cluster bean (Cyamopsis tetragonoloba) seed germination and growth of plants Quest 2: 9-14 